\title{
Müzik Derslerinde Eşlik Kullanımının Müzik Öğretmenleri Görüşleri Doğrultusunda Değerlendirilmesi*
}

\section{The Evaluation of Using Accompaniment in Music Courses through Music Teachers' Opinion}

\section{Barış Kardeş}

Öğr. Gör. Dr., Balıkesir Üniversitesi, Necatibey Eğitim Fakültesi, Güzel Sanatlar Eğitimi Bölümü, Müzik Eğitimi Anabilim Dalı, bariskardes@balikesir.edu.tr

\section{Şirin Akbulut Demirci}

Doç., Uludağ Üniversitesi, Eğitim Fakültesi, Güzel Sanatlar Eğitimi Bölümü, Müzik Eğitimi Anabilim Dalı, akbulut.sirin@gmail.com

* Bu çalışma, Barış Kardeş’e ait, “Müzik Eğitiminde Kullanılan Şarkıların Eşliklenmesine Yönelik Materyal Geliştirme ve Kullanılabilirliği” isimli doktora tezinin bir bölümünden üretilmiştir.

\section{$\ddot{\mathbf{O} z}$}

Bu araştırmada, altıncı sınıf müzik dersinde, müzik öğretmenleri tarafindan ders kitabında yer alan şarkıların yanı sıra belirli gün ve haftalarda kullanılan şarkılara eşlik yapabilmek için lisans eğitimleri sürecinde alınan eğitimin yeterliği, hazır eşlikli şarkıların çalınabilmesi, farklı modeller ile eşlik yapabilme ve doğaçlayabilme durumlarının öğretmen görüşleri doğrultusunda belirlenmesi amaçlanmıştır.

Tarama modeli kullanılarak yapılan araştırma, Denizli Merkez ilçelerde, altıncı sınıf müzik derslerine giren müzik öğretmenlerini ve 2015-2016 Eğitim-Öğretim Yılı Bahar dönemi müfredatını kapsamaktadır.

Verilerin analizinde frekans dağılımı ve yüzdelik gibi betimsel istatistiklerden yararlanılmıştır. Araştırmada elde edilen veriler, SPSS 20.0 istatistik paket programı ile çözümlenmiştir.

Araştırmada müzik öğretmenlerinin, lisans eğitimi sürecinde aldıkları eşlik çalma eğitiminin yeterli olmadığı, eşlik çalma becerisinin öğretmenlik yaşantısında beklenen düzeyde kullanılamadığ sonuçlarına ulaşılmıştır.

Anahtar Kelimeler: Müzik eğitimi, Eşlik eğitimi, Eşlik

\begin{abstract}
The purposes of this research is to determine songs used by music teachers for special weeks and days based on course books in the sixth grade music course.

A survey model was used for determining the current situations of the research subjects. The research was carried out with the music teachers and the students who participated in the sixth grade music courses in Denizli Central Regions. In addition, it covers the curriculum of the Spring Semester of 2015-2016 education year.
\end{abstract}


In the analysis of the data, descriptive statistics such as frequency distribution and percentage were used firstly. The findings obtained were analyzed through using SPSS 20.0 (Statistical Package for the Social Sciences).

As a result of the research, it was concluded that the music teacher's accompaniment education during the undergraduate education was not enough, the accompaniment skill could not be used in the expected level in the teaching life.

Keywords: Music education, Accompaniment education, Accompanying

\section{Giriş}

Müzik genel olarak, seslerin belli bir düzen içerisinde, estetik olarak bir araya getirilmesiyle oluşan sanat dalıdır. Uçan'a (1994) göre müzik, "Duygu, düşünce, tasarım ve izlenimleri veya başka gereçlerin de katkısıyla belli durum, olgu ve olayları düzenlenmiş uyuşumlu seslerle, estetik bir yapıda anlatan bir bütündür" (s. 12).

Hayatın içinde kendi varlığını güçlü bir şekilde hissettiren müzik, çeşitli tür ve yapılarıyla her zaman yaşantının bir parçası olmuştur. İnsanlık tarihiyle yaşıt olan müzik, kimi zaman ritimlerle, kimi zaman insan sesleriyle, kimi zaman ise icat edilen basit veya karmaşık yapılı çalgılarla, insan hayatında daima var olmuştur. Müzik bireyin hissettiği duyguya eşlik eden ya da o an işittiği melodiye göre duygu değişiklikleri oluşturan ve hakkında sayısız tanıma sahip olan özel bir yapı/sanattır (Parasız, 2018, s. 253).

Müzik, her zaman insanoğlunun hayatında çeşitli şekillerde yer almıştır. İnsanlar, sevinç ve üzüntülerini müzik yoluyla anlatmışlar, savaş ve barış durumunda da iletişimlerini müzik ile sağlamışlardır. Doğadaki sesleri taklit etmeye çalışmışlar ve buna bağlı olarak kendi ilkel çalgılarını yapmışlardır (Kardeş, 2013, s. 8).

Bozkaya (2001) müzik eğitimini, "Türk eğitim sistemi içinde sanat eğitiminin bir alt boyutu olup bir amaca yönelik olarak estetik temele dayalı müziksel davranış geliştirme ve müziksel kimlik oluşturma süreci” şeklinde tanımlamaktadır (s. 14).

Türkiye'de müzik öğretmenleri eğitim fakültelerine bağlı müzik eğitimi ana bilim dalları aracılığı ile yetiştirilmektedir. Müzik öğretmenleri adayları bu fakülteden meslek yaşantısında kullanacağı, kuramsal bilgiler, genel kültür ve pedagojik formasyon derslerini alarak mezun olmaktadırlar. Aynı zamanda bu eğitim sürecinde öğretmen adaylarına mevcut program dâhilinde sekiz yarıyıl boyuncu zorunlu piyano eğitimi verilmektedir (YÖK, 2006). Piyanonun yerini tam olarak tutmasa da derslerde kullanılabilecek olan elektronik org, çoksesli, evrensel bir çalgı olmasından dolayı oldukça önemlidir. Mark (1996), elektronik orgun, piyanodan daha küçük, daha az maliyetli ve daha kullanılabilir olduğunu belirtmektedir (s. 140) Müzik öğretmenleri bu çalgıları etkili ve olumlu biçimde kullanmalıdırlar. Müzik öğretmenleri klavyeli çalgı grubuna giren bu çalgılar ile solo şarkılar çalabilir, hatta bu şarkılara tek el veya iki el ile eşlikler yaparak daha etkin biçimde kullanmalıdırlar. Ayrıca iyi bir müzik öğretmeninden, aldığı eğitim doğrultusunda bir şarkıyı armonik açıdan analiz edebilmesi, eşlik yazabilmesi, yazdıği eşliği çalabilmesi ya da doğaçlama eşlik yapabilmesi beklenmektedir. Tüm bu beceriler, müzik öğretmeni yetiştiren kurumlarda, farklı derslerle eğitimci adayına kazandırılmaya çalışılmaktadır.

Müzik eğitimi için eşlik oldukça önemli bir unsurdur. Çalgılara eşlik etme dışında, şarkı öğretiminde de yararlı olduğu bilinen eşlik, bir müzik öğretmeni tarafından etkili bir biçimde kullanılmalıdır Eşlik 
yapabilme becerisi eğitim sürecinde öğretmen adaylarına piyanonun yanı sıra farklı dersler ile kazandırılmaktadır. Müzik öğretmeni yetiştiren kurumlardaki dersler incelendiğinde doğrudan ya da dolaylı olarak piyano, armoni-kontrpuan-eşlik, elektronik org eğitimi ve eşlik çalma derslerinin eşlik yapabilme becerisine katkısı olan dersler olduğu görülmektedir (YÖK, 2006).

Eşlik kavramı müzik için oldukça önemli bir kavramdır. Müzik öğretmenleri için büyük önem arz eden eşlik, geçmişten günümüze dek, gerek kendi adı ile gerek ise eşlik ile ilişkili olabilecek diğer dersler içinde kendine yer bulmuştur. Bilgin'e (1998) göre eşlik, bir kompozisyonun ana melodisine ya da ses partisine dayanak oluşturması ya da onu ön plana çıkarması amaçlanan yardımcı parti ya da partiler olarak tanımlanmaktadır (s. 29).

Ortaokul müzik derslerinde, eşlik kullanılmasının öğrenciler üzerinde olumlu yönde etkileri olduğu ve öğrenciler ile öğretmenlerin motivasyonlarını arttırdığı yapılan çalışmalar ile ortaya konulmuştur. Özen (1998), yapmış olduğu çalışmada piyano ile eşlik yapılmasının öğrencilerin müzik dinleme zevki ve alışkanlığı ile müziksel beğeni kazandırması ve geliştirmesi açısından önemli bir yere sahip olduğunu ifade etmiştir. Demirtaş (2011), yedinci sınıf düzeyinde eşlikli müzik dersi yapılmasının, derse olan ilgiyi artırdığını, piyano eşliğinin öğrenciler üzerinde olumlu bir etkiye sahip olduğunu ve deney-kontrol grupları arasında anlamlı farklar oluşturduğunu tespit etmiştir.

$\mathrm{Bu}$ araştırmada, altıncı sınıf müzik dersinde, müzik öğretmenleri tarafından ders kitabında yer alan şarkıların yanı sıra belirli gün ve haftalarda kullanılan şarkılara eşlik yapabilmek için lisans eğitimleri sürecinde alınan eğitimin yeterliği, hazır eşlikli şarkıların çalınabilmesi, farklı modeller ile eşlik yapabilme ve doğaçlayabilme durumlarının öğretmen görüşleri doğrultusunda belirlenmesi amaçlanmıştır. Bu bağlamda araştırmanın problem cümlesi "müzik öğretmenlerinin derslerde eşlik kullanılmasına ilişsin görüşleri nelerdir? şeklinde oluşturulmuştur.

\section{Yöntem}

Araştırmanın konusu ile ilgili mevcut durumların tespit edilmesine yönelik tarama modeli kullanılmıştır. "Tarama modelleri, geçmişte ya da halen var olan bir durumu var olduğu şekliyle betimlemeyi amaçlayan araştırma yaklaşımlarıdır. Araştırmaya konu olan olay, birey ya da nesne, kendi koşulları içinde ve olduğu gibi tanımlanmaya çalışılır. Onları, herhangi bir şekilde değiştirme, etkileme çabası gösterilmez" (Karasar, 2011, s. 77).

Sönmez \& Alacapınar (2014) tarama modelini, "yaşayanların, hali hazırda var olanların, yaşananların ne olduğunun betimlenip açıklanarak ortaya konulması olarak ele alınabilir" şeklinde tanımlamışlardır. Tarama yönteminde gözlenen iş ya da olaya müdahale edilmez ve kontrol altına alınmaya çalışılmaz. Kendi koşulları içinde değerlendirilir.

Araştırmanın çalışma grubunu, Denizli ili ve Denizli iline bağlı ilçe ve köy okullarında görev yapan ve Milli Eğitim Bakanlığı'na bağlı devlet okullarında görev yapan, altıncı sınıf müzik eğitimi dersini yürüten müzik öğretmenleri oluşturmaktadır. Araştırmada müzik dersleri ile belirli gün ve haftalarda en çok kullanılan şarkıları belirlemek ve eşlik eğitimi ile ilgili görüşlerini almak üzere 77 müzik öğretmeninin görüşlerine başvurulmuştur.

Araştırma için gerekli olan ön bilgilerin edinilmesi amacıyla araştırmacı tarafından hazırlanan müzik öğretmenlerinin görüşlerine yönelik anket kullanılmıştır. Anket, eşlik eğitimi ile ilgili görüşleri ve dersler ile belirli gün ve haftalardan kullanılan şarkıların belirlenmesine yönelik hazırlanmış ve 77 kişi tarafından yapılmıştır.

Dersler ile belirli gün ve haftalarda en çok kullanılan şarkılar, araştırmacı tarafından hazırlanan müzik öğretmenlerinin görüşlerine yönelik anket ile belirlenmiştir. Milli Eğitim Bakanlığı altıncı sınıf 
müfredatı bahar yarıyılında yer alan şarkılar ile bahar döneminde yapılması planlanan belirli gün ve haftalarda hangi şarkıların kullanıldığı ankette yer alan kısımda işaretlemiş ve var ise önerileri yazmaları istenmiştir.

Araştırmacı tarafından hazırlanan, müzik öğretmenlerinin eşlik eğitimi ilgili görüşleri ve dersler ile belirli gün ve haftalarda en çok kullanılan şarkıların tespitine yönelik hazırlanan müzik öğretmenlerinin görüşlerini betimlemek üzere frekans dağılımı ve yüzdelik gibi betimsel istatistiklerden yararlanılmıştır. "Betimsel istatistikler, araştırmacının çok sayıdaki veriyi ve bilgiyi daha az sayıda göstergeye indirgemesine, özetlemesine ve onları anlamlı hale getirmesine yardımc1 olur" (Sezgin, 2015, s. 59).

\section{Bulgular ve Yorum}

Araştırmanın problemine yanıt almak amacıyla çalışma grubunda yer alan değişkenlerin frekans dağılımları ve yüzdelik değerleri hesaplanmıştır.

Tablo 1

Müzik öğretmenlerinin şarkı öğretiminde eşlik kullanımı

\begin{tabular}{lcc}
\hline & $f$ & \% \\
\hline Evet & 22 & 28,6 \\
Hayir & 55 & 71,4 \\
Toplam & $\mathbf{7 7}$ & $\mathbf{1 0 0}$ \\
\hline
\end{tabular}

Tablo 1'de müzik öğretmenlerinin şark1 öğretiminde eşlik kullanma durumları incelenmiş, öğretmenlerden 22 'sinin $(\% 28,6)$ derslerde eşlik kullandığı, 55'inin $(\% 71,4)$ ise eşlik kullanmadığ görülmüştür. Elde edilen verilere göre araştırma için görüş bildiren müzik öğretmenlerinin dersler ile belirli gün ve haftalarda şarkı öğretiminde eşlik kullanmayı fazla tercih etmedikleri söylenebilir.

Tablo 2

Müzik öğretmenlerinin "herhangi bir okul şarklsına eşlik yapabilirim" maddesine ilişskin görüşleri

\begin{tabular}{lcc}
\hline & $f$ & $\mathbf{\%}$ \\
\hline Tamamen Katıliyorum & 1 & 1,3 \\
Katıliyorum & 17 & 22,0 \\
Kismen Kat1lyorum & 22 & 28,6 \\
Katılmıorum & 23 & 29,9 \\
Hiç Katılmiyorum & 14 & 18,2 \\
Toplam & $\mathbf{7 7}$ & $\mathbf{1 0 0}$ \\
\hline
\end{tabular}

Tablo 2'de müzik öğretmenlerinin herhangi bir okul şarkısına eşlik yapabilirim maddesine ilişkin olarak elde edilen veriler incelenmiş, öğretmenlerin 1'inin (\%1,3) tamamen kat1lyyorum, 17'sinin $(\% 22,0)$ kat1lyyorum, 22'sinin $(\% 28,6)$ kısmen kat1lıyorum, 23'nün $(\% 29,9)$ katılmıyorum, 14'ünün $(\% 18,2)$ ise hiç katılmıyorum şeklinde görüş bildirdiği görülmüştür. Bu sonuca göre müzik öğretmenlerinin büyük çoğunluğunun kendilerinin herhangi bir şarkıya eşlik edemeyeceğini düşündüğü söylenebilir.

\section{Tablo 3}

Müzik ögrretmenlerinin "herhangi bir okul şarkısına doğaçlama eşlik yapabilirim" maddesine ilişkin görüşleri

\begin{tabular}{llc}
\hline & $\boldsymbol{f}$ & $\mathbf{\%}$ \\
\hline Tamamen Katıliyorum & 2 & 2,6 \\
Katıliyorum & 22 & 28,6 \\
Kismen Katıliyorum & 25 & 32,5 \\
Katılmiyorum & 16 & 20,7 \\
Hiç Katılmiyorum & 12 & 15,6 \\
Toplam & $\mathbf{7 7}$ & $\mathbf{1 0 0}$ \\
\hline
\end{tabular}


Tablo 3'te müzik öğretmenlerinin herhangi bir okul şarkısına doğaçlama eşlik yapabilirim maddesine ilişkin olarak elde edilen veriler incelenmiş, öğretmenlerin 2'sinin $(\% 2,6)$ tamamen katıliyorum, 22 'sinin $(\% 28,6)$ kat1liyorum, 25'inin $(\% 32,5)$ kısmen katılyyorum, 16'sinın $(\% 20,7)$ kat1lmiyorum, 12 'sinin $(\% 15,6)$ ise hiç katılmıyorum şeklinde görüş bildirdiği görülmüştür. Elde edilen verilere göre müzik öğretmenlerinin herhangi bir okul şarkısına doğaçlama eşlik yapabilmeye ilişkin olarak müzik öğretmenlerinin büyük çoğunluğunun kendilerini doğaçlama eşlik yapabilmek için yeterli düzeyde görmedikleri söylenebilir.

Tablo 4

Müzik öğretmenlerinin "eşliği yazılmış olan şarkıları (örn. İzmir Marşı ya da Biz Atatürk Gençleriyiz vb. marşların orijinal eşlikleri) klavyeli çalgllarla zorlanmadan çalabilirim” maddesine ilişkin görüşleri

\begin{tabular}{|c|c|c|}
\hline & $f$ & $\%$ \\
\hline Tamamen Katıliyorum & 9 & 11,7 \\
\hline Katıliyorum & 14 & 18,2 \\
\hline Kismen Kat1liyorum & 23 & 29,8 \\
\hline Katılmiyorum & 30 & 39,0 \\
\hline Hiç Katılmıyorum & 1 & 1,3 \\
\hline Toplam & 77 & 100 \\
\hline
\end{tabular}

Tablo 4'te müzik öğretmenlerinin orijinalde eşliği yazılmış olan şarkıların eşliklerini zorlanmadan çalabilirim maddesine ilişkin olarak elde edilen veriler incelenmiş, müzik öğretmenlerinin 9'unun $(\% 11,7)$ tamamen kat1lyorum, 14'ünün $(\% 18,2)$ kat1lıyorum, 23'ünün $(\% 29,8)$ kısmen kat1lyorum, 30 'unun $(\% 39,0)$ katılmıyorum, 1'inin $(\% 1,3)$ ise hiç katılmıyorum şeklinde görüş bildirdiği görülmüşsür. Elde edilen verilere göre müzik öğretmenlerinin orijinalde eşliği yazılmış olan şarkıları çalma becerisine ilişkin olarak büyük çoğunluğunun kendilerini yetersiz gördükleri ve bu eşlikleri çalamayacaklarını düşündükleri söylenebilir.

Tablo 5

Müzik ögrretmenlerinin "lisans eğitimim sırasında okul şarkılarının eşliğini çalabilmek için yeterli ĕgitimi aldım" maddesine ilişkin görüşleri

\begin{tabular}{lcc}
\hline & $\boldsymbol{f}$ & $\mathbf{\%}$ \\
\hline Tamamen Katıliyorum & 10 & 13,0 \\
Katıliyorum & 14 & 18,2 \\
Kismen Katıliyorum & 20 & 26,0 \\
Katılmiyorum & 25 & 32,5 \\
Hiç Katılmiyorum & 8 & 10,3 \\
Toplam & $\mathbf{7 7}$ & $\mathbf{1 0 0}$ \\
\hline
\end{tabular}

Tablo 5'te müzik öğretmenlerinin lisans eğitiminde eşlik eğitimi ile ilgili yeterli düzeyde eğitim alıp almadıklarını tespit etmeye ilişkin maddenin verileri incelenmiş, müzik öğretmenlerinin 10'unun $(\% 13,0)$ tamamen kat1lyyorum, 14'ünün $(\% 18,2)$ katılıyorum, 20'sinin $(\% 26,0)$ kısmen kat1liyorum, 25 'inin $(\% 32,5)$ katılmıyorum, 8'inin $(\% 10,3)$ ise hiç katılmıyorum şeklinde görüş bildirdiği görülmüştür. $\mathrm{Bu}$ verilere göre müzik öğretmenlerinin büyük çoğunluğunun lisans eğitimi sürecinde okul şarkılarının eşliğini çalabilmek için yeterli düzeyde eğitim almadıkları şeklinde görüş bildirdikleri görülmektedir.

Tablo 6

Müzik öğretmenlerinin "lisans ĕgitimim sırasında aldı̆̆ım eğitim ile okul şarkılarının eşliğini farklı eşlik modelleriyle yapabilirim” maddesine iliş̧kin görüşleri

\begin{tabular}{lcc}
\hline & $f$ & $\mathbf{\%}$ \\
\hline Tamamen Katıliyorum & 9 & 11,7 \\
Katıliyorum & 7 & 9,0 \\
Kismen Katıliyorum & 29 & 37,7 \\
Katılmıorum & 30 & 39,0 \\
Hiç Katılmiyorum & 2 & 2,6 \\
Toplam & $\mathbf{7 7}$ & $\mathbf{1 0 0}$ \\
\hline
\end{tabular}


Tablo 6'da müzik öğretmenlerinin lisans eğitimi süresince farklı eşlik modellerini öğrenmeye yönelik eğitim alıp almadıklarını tespit etmeye ilişkin maddenin verileri incelenmiş, müzik öğretmenlerinin 9'unun (\%11,7) tamamen kat1liyorum, 7'sinin $(\% 9,0)$ katıliyorum, 29'unun $(\% 37,7)$ kısmen katılıyorum, 30'unun $(\% 39,0)$ katılmıorum, 2'sinin $(\% 2,6)$ ise hiç katılmıyorum şeklinde görüş bildirdiği görülmüştür. $\mathrm{Bu}$ verilere göre müzik öğretmenlerinin büyük çoğunluğunun lisans eğitimi sürecinde farklı eşlik modellerini öğrenmeye yönelik yeterli düzeyde eğitim almadıkları söylenebilir.

Tablo 7

Müzik ögretmenlerinin "lisans eğitimim sırasında aldı̆̆ım armoni eğitimi ile okul şarklarına kolaylıkla eşlik yapabilirim” maddesine ilişkin görüşleri

\begin{tabular}{lcc}
\hline & $f$ & $\mathbf{\%}$ \\
\hline Tamamen Katıliyorum & 0 & 0 \\
Katılıyorum & 17 & 22,0 \\
Kismen Katıliyorum & 28 & 36,4 \\
Katılmiyorum & 24 & 31,2 \\
Hiç Katılmiyorum & 8 & 10,4 \\
Toplam & $\mathbf{7 7}$ & $\mathbf{1 0 0}$ \\
\hline
\end{tabular}

Tablo 7'de müzik öğretmenlerinin lisans eğitimi süresince aldıkları armoni eğitimi ile okul şarkılarına kolayca eşlik yapabilme becerisine ilişkin maddenin verileri incelenmiş, müzik öğretmenlerinin 17 'sinin $(\% 22,0)$ katılıyorum, 28'inin $(\% 36,4)$ kısmen katılıyorum, 24'ünün $(\% 31,2)$ katılmıyorum, 8 'inin $(\% 10,4)$ hiç katılmıyorum şeklinde görüş bildirdiği görülmüştür. Bu verilere göre müzik öğretmenlerinin büyük çoğunluğunun aldıkları armoni eğitiminin eşlik yapabilmek için yeterli düzeyde olmadı̆̆ı söylenebilir.

Tablo 8

Müzik ögretmenlerinin "lisans eğitimim sırasında aldığım eğitim ile makamsal şarkılara da kolaylıkla eşlik yapabilirim" maddesine iliş̧kin görüşleri

\begin{tabular}{lcc}
\hline & $\boldsymbol{f}$ & $\mathbf{\%}$ \\
\hline Tamamen Katıliyorum & 9 & 11,7 \\
Katılıyorum & 8 & 10,4 \\
Kismen Katıliyorum & 23 & 29,9 \\
Katılmiyorum & 27 & 35,0 \\
Hiç Katılmiyorum & 10 & 13,0 \\
Toplam & $\mathbf{7 7}$ & $\mathbf{1 0 0}$ \\
\hline
\end{tabular}

Tablo 8'de müzik öğretmenlerinin lisans eğitimi süresince aldıkları eğitim ile makamsal şarkılara kolaylıkla eşlik yapabilme becerisine ilişkin maddenin verileri incelenmiş, müzik öğretmenlerinin 9'unun (\%11,7) tamamen katılıyorum, 8'inin $(\% 10,4)$ katıliyorum, 23'ünün (\%29,9) kısmen katılıyorum, 27'sinin $(\% 35,0)$ katılmıyorum, 10'unun $(\% 13,0)$ ise hiç katılmıyorum şeklinde görüş bildirdiği görülmüştür. $\mathrm{Bu}$ verilere göre müzik öğretmenlerinin büyük çoğunluğunun makamsal şarkıların eşliğine yönelik eğitimin yeterli düzeyde olmadığı görüşünde oldukları söylenebilir.

Tablo 9

Müzik öğretmenlerinin "sınıfta ders yaparken okul şarkılarına eşlik yapmayı gereksiz buluyorum" maddesine iliş̧kin görüşleri

\begin{tabular}{lcc}
\hline & $f$ & $\mathbf{\%}$ \\
\hline Tamamen Kat1liyorum & 3 & 3,9 \\
Kat1lyorum & 1 & 1,3 \\
Kismen Katıliyorum & 1 & 1,3 \\
Katılmıyorum & 20 & 26,0 \\
Hiç Katılmıorum & 52 & 67,5 \\
Toplam & $\mathbf{7 7}$ & $\mathbf{1 0 0}$ \\
\hline
\end{tabular}

Tablo 9'da müzik öğretmenlerinin sınıfta ders yaparken eşlik yapmayı gereksiz buluyorum maddesine ilişkin veriler incelenmiş, müzik öğretmenlerinin 3'ünün $(\% 3,9)$ tamamen katılıyorum, 1'inin $(\% 1,3)$ kat1lıyorum, 1'inin $(\% 1,3)$ kısmen katılıyorum, 20'sinin $(\% 26,0)$ katılmıyorum, 52 'sinin $(\% 67,5)$ ise 
hiç katılmıyorum şeklinde görüş bildirdiği görülmüştür. Bu verilere göre müzik öğretmenlerinin tamamına yakınının derslerde eşlik yapmayı gerekli gördükleri söylenebilir.

Tablo 10

Müzik öğretmenlerinin "keşke lisans eğitimim sirasında eşlik yapabilmeyle ilgili olarak kendimi daha çok gelişsirseydim” maddesine ilişkin görüşleri

\begin{tabular}{lcc} 
& $f$ & $\%$ \\
\hline Tamamen Katılıyorum & 42 & 54,5 \\
Katılıyorum & 16 & 20,8 \\
Kismen Katıliyorum & 12 & 15,6 \\
Katılmıyorum & 6 & 7,8 \\
Hiç Katılmıyorum & 1 & 1,3 \\
Toplam & 77 & $\mathbf{1 0 0}$ \\
\hline
\end{tabular}

Tablo 10'da müzik öğretmenlerinin lisans eğitimi sürecinde eşlik yapabilme ile ilgili kendimi daha çok geliştirseydim maddesine ilişkin veriler incelenmiş, müzik öğretmenlerinin 42 'sinin $(\% 54,5)$ tamamen katılıyorum, 16'sının $(\% 20,8)$ katılıyorum, 12'sinin $(\% 15,6)$ kısmen katılıyorum, 6'sının $(\% 7,8)$ katılmıyorum, 1'inin $(\% 1,3)$ ise hiç katılmıyorum şeklinde görüş bildirdiği görülmüştür. $\mathrm{Bu}$ verilere göre müzik öğretmenlerinin lisans eğitiminde eşlik yapabilmeye çok önem vermedikleri ancak meslek yaşantılarında bu eksikliği hissettikleri söylenebilir.

Tablo 11

Müzik öğretmenlerinin "lisans eğitimim sırasında eğitimcilerim eşlik yapmanın önemine yönelik beni ikna ettiler" maddesine ilişkin görüşleri

\begin{tabular}{lcc}
\hline & $f$ & $\%$ \\
\hline Tamamen Katıliyorum & 14 & 18,2 \\
Katıllyorum & 10 & 13,0 \\
Kismen Katıliyorum & 17 & 22,0 \\
Katılmıorum & 28 & 36,4 \\
Hiç Katılmyorum & 8 & 10,4 \\
Toplam & 77 & $\mathbf{1 0 0}$ \\
\hline
\end{tabular}

Tablo 11'de lisans eğitimi sürecinde eğitimcilerim eşlik yapabilmenin önemi konusunda beni ikna ettiler maddesine ilişkin veriler incelenmiş, müzik öğretmenlerinin 14'ünün $(\% 18,2)$ tamamen kat1liyorum, 10'unun $(\% 13,0)$ kat1lyorum, 17'sinin $(\% 22,0)$ kısmen kat1lyorum, 28'inin $(\% 36,4)$ katılmıyorum, 8'inin $(\% 10,4)$ ise hiç katılmıyorum şeklinde görüş bildirdiği görülmüştür. Bu verilere göre müzik öğretmenleri lisans eğitimi sürecinde, eğitimcilerin eşlik yapmanın önemini yeterli düzeyde vurgulamadıklarını belirtmişlerdir.

Tablo 12

Müzik ögretmenlerinin "ilk defa gördüğüm bir okul şarkısına hemen eşlik yapabilirim” maddesine ilişskin görüşleri

\begin{tabular}{lcc}
\hline & $f$ & $\%$ \\
\hline Tamamen Katılıyorum & 1 & 1,3 \\
Katılıyorum & 15 & 19,4 \\
Kismen Katıliyorum & 28 & 36,4 \\
Katılmıyorum & 19 & 24,7 \\
Hiç Katılmyorum & 14 & 18,2 \\
Toplam & $\mathbf{7 7}$ & $\mathbf{1 0 0}$ \\
\hline
\end{tabular}

Tablo 12'de müzik öğretmenlerinin ilk defa gördükleri bir okul şarkısına hemen eşlik yapabilirim maddesine ilişkin verileri incelenmiş, müzik öğretmenlerinin 1'inin $(\% 1,3)$ tamamen katılıyorum, 15 'inin $(\% 19,4)$ kat1liyorum, 28 'inin $(\% 36,4)$ kısmen katılıyorum, 19'unun $(\% 24,7)$ katılmiyorum, 14 'ünün $(\% 18,2)$ ise hiç katılmıyorum şeklinde görüş bildirdiği görülmüştür. Elde edilen verilere göre müzik öğretmenlerinin büyük çoğunluğunun ilk defa gördükleri bir okul şarkısına eşlik yapabilmeye ilişkin kendilerini yeterli düzeyde görmedikleri söylenebilir. 
Tablo 13

Müzik ögrretmenlerinin "derslerde ya da belirli gün ve haftalara ilişsin etkinliklerde kullanmak üzere eşlik bulabilirim” maddesine ilişskin görüşleri

\begin{tabular}{lcc}
\hline & $f$ & $\mathbf{\%}$ \\
\hline Tamamen Katılyyorum & 10 & 13,0 \\
Katılıyorum & 16 & 20,8 \\
Kismen Kat1lyorum & 19 & 24,7 \\
Katılmıyorum & 29 & 37,6 \\
Hiç Katılmiyorum & 3 & 3,9 \\
Toplam & $\mathbf{7 7}$ & $\mathbf{1 0 0}$ \\
\hline
\end{tabular}

Tablo 13'te müzik öğretmenlerinin dersler ile belirli gün ve haftalara ilişkin etkinliklerde kullanmak üzere eşlik bulabilirim maddesine ilişkin verileri incelenmiş, müzik öğretmenlerinin 10'unun $(\% 13,0)$ tamamen kat1lyorum, 16'sinın (\%20,8) kat1lyyorum, 19'unun $(\% 24,7)$ k1smen kat1liyorum, 29'unun $(\% 37,6)$ katılmıyorum, 3 'ünün $(\% 3,9)$ ise hiç katılmıyorum şeklinde görüş bildirdiği görülmüştür. Elde edilen verilere göre müzik öğretmenlerinin büyük çoğunluğunun dersler ile belirli gün ve haftalarda kullanılmak üzere yeterince eşlik bulamadıkları söylenebilir.

\section{Tablo 14}

Müzik öğretmenlerinin "bence eşlik yapabilmek için yararlanabileceğimiz yeterli sayıda kaynak var" maddesine ilişkin görüşleri

\begin{tabular}{lcc}
\hline & $\boldsymbol{f}$ & $\mathbf{\%}$ \\
\hline Tamamen Katıliyorum & 3 & 3,9 \\
Katıliyorum & 3 & 3,9 \\
Kismen Katıliyorum & 18 & 23,4 \\
Katılmiyorum & 37 & 48,0 \\
Hiç Katılmiyorum & 16 & 20,8 \\
Toplam & $\mathbf{7 7}$ & $\mathbf{1 0 0}$ \\
\hline
\end{tabular}

Tablo 14'te müzik öğretmenlerinin eşlik yapabilmek için yeterli sayıda kaynak var maddesine ilişkin verileri incelenmiş, müzik öğretmenlerinin 3'ünün $(\% 3,9)$ tamamen kat1lyyorum, 3'ünün $(\% 3,9)$ kat1lıyorum, 18 'inin $(\% 23,4)$ kısmen kat1liyorum, 37'sinin $(\% 48,0)$ katılmıyorum, 16 'sinın $(\% 20,8)$ ise hiç katılmıyorum şeklinde görüş bildirdiği görülmüştür. Elde edilen verilere göre müzik öğretmenlerinin büyük çoğunluğunun eşlik yapabilmek için yararlanabilecekleri yeterince kaynağa ulaşamadıkları söylenebilir.

Tablo 15

Müzik öğretmenlerinin "eşlik yapabilmek için okul imkânlarının yeterli olduğunu düşünüyorum” maddesine ilişskin görüşleri

\begin{tabular}{llc}
\hline & $f$ & $\mathbf{\%}$ \\
\hline Tamamen Katıliyorum & 4 & 5,2 \\
Katıliyorum & 16 & 20,8 \\
Kismen Katıliyorum & 11 & 14,3 \\
Katılmiyorum & 20 & 26,0 \\
Hiç Katılmiyorum & 26 & 33,7 \\
Toplam & $\mathbf{7 7}$ & $\mathbf{1 0 0}$ \\
\hline
\end{tabular}

Tablo 15'te müzik öğretmenlerinin görev yaptıkları okuldaki imkânların yeterli olup olmadığını saptamaya yönelik maddeye ilişkin verileri incelenmiş, müzik öğretmenlerinin 4'ünün $(\% 5,2)$ tamamen kat1lyorum, 16'sinın (\%20,8) kat1liyorum, 11'inin (\%14,3) kısmen kat1liyorum, 20'sinin $(\% 26,0)$ katılmıyorum, 26'sının $(\% 33,7)$ ise hiç katılmıyorum şeklinde görüş bildirdiği görülmüştür. Elde edilen verilere göre müzik öğretmenlerinin büyük çoğunluğunun okul imkânlarını istenen düzeyde bulmadıkları söylenebilir. 
Tablo 16

Müzik öğretmenlerinin "derslerde eşlik yapmanın derse katılımı arttırdı̆̆ını düşünmekteyim” maddesine ilişskin görüşleri

\begin{tabular}{lcc}
\hline & $f$ & $\mathbf{\%}$ \\
\hline Tamamen Katıliyorum & 52 & 67,5 \\
Katıliyorum & 19 & 24,7 \\
Kismen Katılıyorum & 6 & 7,8 \\
Katılmiyorum & 0 & 0 \\
Hiç Katılmiyorum & 0 & 0 \\
Toplam & $\mathbf{7 7}$ & $\mathbf{1 0 0}$ \\
\hline
\end{tabular}

Tablo 16'da müzik öğretmenlerinin derslerde eşlik yapmanın derse katılımını arttırdığını düşünmekteyim maddesine ilişkin verileri incelenmiş, müzik öğretmenlerinin 52 'sinin $(\% 67,5)$ tamamen katılıyorum, 19'unun (\%24,7) katılıyorum, 6'sının (\%7,8) kısmen katılıyorum şeklinde görüş bildirdiği görülmüştür. Elde edilen verilere göre müzik öğretmenleri derslerde eşlik yapmanın, derse katılımı arttırdığını belirtmektedir.

\section{Tablo 17}

Müzik öğretmenlerinin "derslerde eşlik yapmanın, öğrencilerin şarkları doğru ritim ile söylemelerine/çalmalarına büyük katkısı olduğunu düşünmekteyim” maddesine iliş̧kin görüşleri

\begin{tabular}{lcc}
\hline & $f$ & $\mathbf{\%}$ \\
\hline Tamamen Katıliyorum & 61 & 79,2 \\
Katıliyorum & 14 & 18,2 \\
Kismen Katıliyorum & 2 & 2,6 \\
Katılmiyorum & 0 & 0 \\
Hiç Katılmiyorum & 0 & 0 \\
Toplam & $\mathbf{7 7}$ & $\mathbf{1 0 0}$ \\
\hline
\end{tabular}

Tablo 17'de müzik öğretmenlerinin derslerde eşlik yapmanın öğrencilerin şarkıları doğru ritim ile söylemelerine/çalmalarına büyük katkısı olduğunu düşünmekteyim maddesine ilişkin verileri incelenmiş, müzik öğretmenlerinin 61'inin $(\% 79,2)$ tamamen kat1lyyorum, 14'ünün $(\% 18,2)$ katılıyorum, 2'sinin $(\% 2,6)$ kısmen katılıyorum şeklinde görüş bildirdiği görülmüştür. Elde edilen verilere göre müzik öğretmenlerinin büyük çoğunluğu, derslerde eşlik yapmanın doğru ritim ile söylemelerine/çalmalarına önemli katkı sağladığını belirtmişlerdir.

Tablo 18

Müzik ögretmenlerinin "derslerde eşlik yapmanın, öğrencilerin şarkıları tonda kalarak söylemelerine büyük katklsı olduğunu düşünmekteyim” maddesine ilişkin görüşleri

\begin{tabular}{lcc}
\hline & $f$ & $\mathbf{\%}$ \\
\hline Tamamen Katılıyorum & 62 & 80,5 \\
Katıliyorum & 15 & 19,5 \\
Kismen Katıliyorum & 0 & 0 \\
Katılmiyorum & 0 & 0 \\
Hiç Katılmiyorum & 0 & 0 \\
Toplam & $\mathbf{7 7}$ & $\mathbf{1 0 0}$ \\
\hline
\end{tabular}

Tablo 18 'de müzik öğretmenlerinin derslerde eşlik yapmanın öğrencilerin şarkıları tonda kalarak ile söylemelerine katkısı olduğunu düşünüyorum maddesine ilişkin verileri incelenmiş, müzik öğretmenlerinin 62'sinin $(\% 80,5)$ tamamen katıllyorum, 15'inin $(\% 19,5)$ katıllyorum, şeklinde görüş bildirdiği görülmüş̧ür. Elde edilen verilere göre müzik öğretmenlerinin tamamının derslerde eşlik yapmanın öğrencilerin tonda kalarak şark1 söylemelerinde etkili olduğunu düşündükleri görülmüştür. 
Barış Kardeş, Şirin Akbulut Demirci

Müzik Derslerinde Eşlik Kullanımının Müzik Öğretmenleri Görüșleri Doğrultusunda Değerlendirilmesi GSED 42 - DOI: 10.32547/ataunigsed.500672

Tablo 19

Müzik ögretmenlerinin dersler ile belirli gün ve haftalarda en çok kullanılan şarkılar

\begin{tabular}{|c|c|c|c|}
\hline & & $f$ & $\%$ \\
\hline \multirow{2}{*}{ Kahraman } & Evet & 30 & 39,0 \\
\hline & Hayır & 47 & 61,0 \\
\hline \multirow{2}{*}{ Karlı Dağlar } & Evet & 61 & 79.2 \\
\hline & Hayır & 16 & 20.8 \\
\hline \multirow{2}{*}{ Akvaryum } & Evet & 31 & 40.3 \\
\hline & Hayır & 46 & 59.7 \\
\hline \multirow{2}{*}{ Neşeli Günler } & Evet & 68 & 88.3 \\
\hline & Hayır & 9 & 11.7 \\
\hline \multirow{2}{*}{ Sazıma } & Evet & 31 & 40.3 \\
\hline & Hayır & 46 & 59.7 \\
\hline \multirow{2}{*}{ Yurdumda } & Evet & 63 & 81,8 \\
\hline & Hayır & 14 & 18,2 \\
\hline \multirow{2}{*}{ Bilal Oğlan } & Evet & 47 & 61,0 \\
\hline & Hayır & 30 & 39,0 \\
\hline \multirow{2}{*}{ Bülbülüm } & Evet & 57 & 74,0 \\
\hline & Hayır & 20 & 26,0 \\
\hline \multirow{2}{*}{ Dere } & Evet & 42 & 54,5 \\
\hline & Hayır & 35 & 45,5 \\
\hline \multirow{2}{*}{ Üç Alma } & Evet & 52 & 67,5 \\
\hline & Hayır & 25 & 32,5 \\
\hline \multirow{2}{*}{ Okula Başladık } & Evet & 31 & 40,3 \\
\hline & Hayır & 46 & 59,7 \\
\hline \multirow{2}{*}{ Atatürk } & Evet & 61 & 79,2 \\
\hline & Hayır & 16 & 20,8 \\
\hline \multirow{2}{*}{ Yenice Yolları } & Evet & 62 & 80,5 \\
\hline & Hayır & 15 & 19,5 \\
\hline & Evet & 65 & 84,4 \\
\hline Sevg1 Çıçeklerı & Hayır & 12 & 15,6 \\
\hline Cumburivet Marci & Evet & 70 & 90,9 \\
\hline Cumnuriyet IMarşı & Hayır & 7 & 9,1 \\
\hline & Evet & 71 & 92,2 \\
\hline Gençlik Marşı & Hayır & 6 & 7,8 \\
\hline & Evet & 63 & 81,8 \\
\hline Bız Ataturk Gençlerıyız & Hayır & 14 & 18,2 \\
\hline & Evet & 66 & 85,7 \\
\hline Izindeyiz & Hayır & 11 & 14,3 \\
\hline İleri Mars & Evet & 66 & 85,7 \\
\hline Mer1 Marşı & Hayır & 11 & 14,3 \\
\hline & Evet & 55 & 71,4 \\
\hline Vatan Marşı & Hayır & 22 & 28,6 \\
\hline & Evet & 67 & 87,0 \\
\hline Cumhurıyet Marşı & Hayır & 10 & 13,0 \\
\hline & Evet & 64 & 83,1 \\
\hline Atam & Hayır & 13 & 16,9 \\
\hline Öŏretmen Marsı & Evet & 70 & 90,9 \\
\hline Ugretmen Marşı & Hayır & 7 & 9,1 \\
\hline Sen Varsin Hen Ö̆̆retmenim & Evet & 60 & 77,9 \\
\hline Sen Varsin Hep Ugretmenım & Hayır & 17 & 22,1 \\
\hline & Evet & 41 & 53,2 \\
\hline Ogretmen & Hayır & 36 & 46,8 \\
\hline Canakkale Türkë̈сї & Evet & 72 & 93,5 \\
\hline Çanakkale I urkusu & Hayır & 5 & 6,5 \\
\hline & Evet & 70 & 90,9 \\
\hline Yemen Tưrküsü & Hayır & 7 & 9,1 \\
\hline & Evet & 56 & 72,7 \\
\hline Çalın Davulları & Hayır & 21 & 27,3 \\
\hline & Evet & 61 & 79,2 \\
\hline 23 Nisan Kutlu Olsun & Hayır & 16 & 20,8 \\
\hline FlFle Verelim & Evet & 66 & 85,7 \\
\hline El Ele verelim & Hayır & 11 & 14,3 \\
\hline Bayrağım (Atalarım Gökten & Evet & 46 & 59,7 \\
\hline Yere) & Hayır & 31 & 40,3 \\
\hline & Evet & 44 & 57,1 \\
\hline Bayrağım & Hayır & 33 & 42,9 \\
\hline Yirmi Üs Nisan & Evet & 63 & 81,8 \\
\hline Y irmi Uç Nisan & Hayır & 14 & 18,2 \\
\hline & Evet & 55 & 71,4 \\
\hline Dumlupınar & Hayır & 22 & 28,6 \\
\hline
\end{tabular}


Tablo 19'da müzik öğretmenlerinin görüşleri doğrultusunda dersler ile belirli gün ve haftalarda en çok kullandıkları şarkıların dağılımları incelenmiş; Karlı Dağlar, Neşeli Günler, Yurdumda, Bilal Oğlan, Bülbülüm, Dere, Üç Alma, Atatürk, Yenice Yolları, Sevgi Çiçekleri, Cumhuriyet Marşı, Gençlik Marşı, Biz Atatürk Gençleriyiz, İzindeyiz, İleri Marşı, Vatan Marşı, Cumhuriyet Marşı, Atam, Öğretmen Marşı, Sen Varsın Hep Öğretmenim, Öğretmen, Çanakkale Türküsü, Yemen Türküsü, Çalın Davulları, 23 Nisan Kutlu Olsun, El Ele Verelim, Bayrağım (Atalarım Gökten Yere), Bayrağım, Yirmi Üç Nisan ve Dumlupınar şarkılarının en çok kullanılan şarkılar olduğu tespit edilmiştir. Elde edilen verilere göre araştırma için görüş bildiren müzik öğretmenlerinin, belirli gün ve haftalarda, marşlar ve halk türkülerinden oluşan bir repertuvar kullandıkları söylenebilir.

\section{Sonuç, Tartışma ve Öneriler}

İlk olarak müzik öğretmenlerinin lisans eğitimleri sürecinde eşlik yapmaya yönelik aldıkları eğitimin içeriği ve bu eğitim ile ilgili görüşleri, müzik öğretmenlerinin görüşlerine yönelik anket ile toplanmıştır. Buna göre öğretmenlerin lisans eğitimi sürecinde eşlik yapabilmeye yönelik aldıkları armoni-kontrpuan-eşlik, piyano eğitimi derslerine gereken özeni göstermedikleri, eşlik eğitimi ile ilgili dersleri yürüten öğretim elemanlarının, öğrencileri yeterince yönlendiremediği sonuç olarak elde edilmiştir. Bununla beraber öğretmenlik yaşantılarında eşlik yapmanın önemini kavradıkları fakat yeterli sayıda eşlik materyalinin bulunamadığı, var olan eşliklerin zor olduğu, doğaçlama eşlik yapamadıkları, kaynak kitap bulamadıkları ayrıca okulların fiziki şartlarının yeterli olmadığı sonucuna ulaşılmıştır.

Araştırmadan elde edilen bulgular incelendiğinde, lisans eğitimi süresince verilen ve müzik öğretmenliği programında kazandırılması hedeflenen eşlik yapabilme becerisinin, öğretmenler tarafından öğretmenlik yaşantısında beklenen düzeyde kullanmadıkları tespit edilmiştir. Müzik öğretmenlerinin derslerde eşlik kullanmadıkları, herhangi bir okul şarkısına eşlik yapabilme, eşliği bulunmayan ve deşifre olarak okunan bir şarkıya doğaçlama eşlik yapabilme veya eşliği hazır olan bir şarkının eşliğini çalabilme konusunda kendilerini yetersiz hissettikleri, lisans eğitimi süresince aldıkları eşlik eğitimini yeterli düzeyde görmedikleri tespit edilmiştir. Bu durum müzik öğretmenliği programında yer alan eşlik eğitimi ile ilgili kazanımlarla örtüşmediği ve eşlik çalabilme becerisinin müzik öğretmenleri bakımından beklendik düzeyde kazanılmadığı söylenebilir. Müzik öğretmenliği lisans eğitimi ders içeriklerinde bazı dersler aracılığ ile eşlik becerisi kazanımlarına yer verilmiş fakat bu eğitimin yalnızca teorik bilgi olarak kaldığı, uygulama aşamasında yetersizlik olduğu ve müzik öğretmenlerinin bu kazanımları meslek yaşantılarına yeterince aktaramadıkları görülebilmektedir.

Müzik öğretmenlerinin doğaçlama eşlik yapabilmesi, müzik öğretmenliği programlarında aldıkları eğitim doğrultusunda beklenen bir durumdur. Ancak meslek yaşantısında gerek alınan eğitimin yetersiz kalması gerek ise uygulama eksikliğinden kaynaklanan durumlardan dolayı bu beceri yeterli düzeyde kullanılamamaktadır. Çizili (2000) yapmış olduğu "Müzik Öğretmenliği Programları Mezunlarının Piyano Derslerinde Öğrendikleri Davranışları Öğretmenlikte Kullanmaları" konulu araştırmada, müzik öğretmenlerinin piyano ya da klavye ile okul şarkılarına doğaçlama eşlik yapmalarında yeterlik durumlarını saptamayı amaçlamış, müzik öğretmenlerinin çoğunun piyanoda doğaçlama eşlik yapabilme davranışında yetersiz veya kısmen yeterli oldukları sonucunu elde etmiştir. Öztürk (2001) yapmış olduğu "İlköğretim Kurumlarında Görev Yapmakta Olan Müzik Öğretmenlerinin Çalgılarını Kullanmadaki Yeterlilik Durumları" adlı yüksek lisans tezinde, öğretmenlerin çalgılarından, şarkılara eşlik etme ve şarkı öğretiminde faydalanma durumlarını saptamayı amaçlamış, müzik öğretmenlerinin \%67.5'nun çalgılarıyla şarkıya eşlik etmede yetersiz olduklarını tespit etmiştir. Propst (2003) yapmış olduğu "Sınıflarda Kullanımı ile Lisans Müzik Eğitimi Sınıf Müfredatı Arasındaki İlişki”" adlı araştırmada, aktivitelerde piyano kullanımı ile ilgili 
olarak, birçok müzik öğretmeninin piyano çalma, melodi çalma ve şark1 söyleme konusunda kendilerini yeterli hissetmedikleri sonucuna ulaşmıştır. Eğilmez (2003) tarafindan yapılan "Türkiye'de Müzik Öğretmeni Yetiştiren Kurumlardaki Piyano Öğretiminin Müzik Öğretmenlerinin Müzik Derslerinde Piyano/Elektronik Orgu Kullanabilme Yeterliklerine İlişkin Görüşleri Doğrultusunda Değerlendirilmesi" adlı araştırmada müzik öğretmenlerinin okul şarkılarına piyano/elektronik org ile eşlik edebilme davranışını gerçekleştirmede, kendilerini "Tamamen" veya "Büyük ölçüde" yeterli gördüklerini, diğer yarısının ise "kısmen" ve "çok az" yeterli veya "yetersiz" gördüklerini tespit etmiş, kendilerini yeterli bulma oranlarının düşük olması sebebiyle müzik öğretmeni yetiştiren kurumlardaki piyano öğretim programlarında yapılan uygulamaların yeteri kadar amacına ulaşmadığını sonucuna ulaşmiştır.

Müzik öğretmenlerinin meslek yaşantılarında eşlik çalabilme becerisini beklenen düzeyde ve program hedefleri doğrultusunda gerçekleştirebilmeleri için, lisans eğitimi sürecinde almış oldukları eğitimin yeterli düzeyde olması gerektirmektedir. Araştırma bağlamında elde edilen bilgiler doğrultusunda, öğretmenlerin şarkıları armonik açıdan inceleyerek çözümleyebildikleri, ancak yeterli piyano çalma becerisine sahip olmadıkları için eşlik yapma konusunda zorluklar yaşadıkları; lisans eğitimi süresince aldıkları eğitimin farklı eşlik modelleri öğrenebilmeleri konusunda yetersiz olduğu, alınan eğitimin yeterli armoni bilgisine sahip olmalarını sağlamadığı ve dolayısıyla eşlik yaparken armoni bilgisinin yetersiz olduğunu, tonal müzik armonisinin yanı sıra makamsal müzik armonisi hakkında yeterli bilgiye sahip olunmamasından dolayı makamsal şarkılara eşlik yapabilme konusunda kendilerini yetersiz gördükleri tespit edilmiştir. Bu durumun ders içeriğinin yeterince iyi olmaması, eğitimciden kaynaklı sorunlar, öğrenciden kaynaklı sorunlar, ders saatlerinin az olması ve uygulama yetersizliği gibi nedenlerden kaynaklandığı söylenebilir. Kutluk (2001) yapmış olduğu, "Türkiye'deki Müzik Öğretmeni Yetiştiren Kurumlarda Piyano Eğitimi” çalışmasında, piyano ile okul şarkılarını eşliklemede müzik öğretmeni adaylarının, şarkıların armonilerini analiz etmede, şarkı yapısına uygun eşlik modeli bulmakta ve piyano çalma ile ilgili teknik yetersizlikler olduğunu tespit etmiştir. Kutluk'un elde ettiği bu bulgular, bu araştırmanın sonucuyla birbirini destekler niteliktedir. Milli (1999) yapmış olduğu "İlköğretim Okullarında Piyano ve Klavyeli Çalgıların Müzik Öğretmenleri Tarafından Kullanımı ve Eğitime Katkıları" adlı yüksek lisans tezinde, öğrencilerin lisans dönemi boyunca almış oldukları piyano ve eşlik derslerinin süre ve içerik bakımından yetersiz olduğu sonucuna ulaşmıştır. Koçak (2001) tarafından yapılan "Müzik Eğitimcisi Yetiştiren Kurumlardaki Piyano ile Eşlik Faaliyetleri” adlı yüksek lisans çalışmasında, piyano çalma düzeylerinin, piyano ile eşlik yapma açısından yetersiz göründüğü, eşlik dersinin öğrencinin eşlik yapması için süre ve kapsam bakımından yetersiz kaldığı sonuçlarını elde etmiştir.

Eşlik yapılırken doğru eşlik modellerinin kullanılması oldukça önem arz etmektedir. Gülhan (1990) tarafından yapılan "Orta Dereceli Okullardaki Müzik Eğitiminde Piyanonun Bir Eşlik Çalgısı Olarak Kullanılabilirliği" adlı yüksek lisans tezinde, şarkıların armonik analizinin doğru yapılmasının ve sol elin, ezgiyi uygun eşlik modelleriyle desteklenmesi gerektiğini vurgulamıştır.

Eşliği yapılan şarkının türü, hızı, ölçü sayısı gibi değişkenler eşlik modelini etkilemektedirler. Doğru ve estetik açıdan güzel bir eşlik modeli kullanmak ise armoni bilgisinin yanında yeterli düzeyde piyano çalabilme becerisiyle bağlantılıdır. Yapılan araştırmalarda müzik öğretmenlerinin, eşlikleme yaparken farklı eşlik modelleri kullanamadıklarını ve genellikle çalması daha basit olan modelleri tercih ettiklerini göstermektedir. Kutluk (2001) tarafından yapılan "Türkiye'deki Müzik Öğretmeni Yetiştiren Kurumlarda Piyano Eğitimi” adlı çalışmasında, müzik öğretmenlerinin şarkı yapısına uygun eşlik modeli bulmakta ve piyano çalma ile ilgili teknik yetersizlikler olduğunu tespit etmiştir. Kardeş (2013) yapmış olduğu "Eğitim Fakültesi Güzel Sanatlar Eğitimi Bölümü Müzik Eğitimi Ana Bilim Dalı Programlarında Kazandırılan Eşlik Yapabilme Becerisinin Program Hedeflerine Ulaşma 
Durumu" isimli yüksek lisans tezinde, müzik öğretmeni adaylarının, akor seslerinin aynı anda temel durumda veya çevrim olarak birlik ve ikilik notalar halinde çalındığı eşlik modelinin en çok kullanılan eşlik modeli olduğunu, öğrencilerin basit ve karmaşı olmayan modelleri tercih ettiği sonucuna ulaşmıştır.

Yapılan araştırmada derslerde eşlik yapılmasının gerekli olduğu, lisans eğitimi süresince eşlik eğitimine öğretmen adayı olarak daha fazla önem vermeleri gerektiği, öğretim elemanlarının eğitim süresince öğretmen adaylarını eşlik yapabilmenin önemi konusunu yeterince vurgulamadığı, müzik öğretmenlerinin derslerde ya da belirli gün ve haftalara ilişkin etkinliklerde kullanmak üzere eşlik bulamadıkları, eşlik yapmalarına yardımcı olabilecek, yöntemler konusunda bilgiler edinebilecekleri yeterli kaynak bulunmadığı, okullarında eşlik yapabilmek üzere kullanabilecekleri piyanonun bulunmadığı fakat eşlik yapabilmek için elektronik org bulunduğu sonuçlanı elde edilmiştir. Müzik öğretmenlerinin eşlik konusunda kendilerini geliştirebilmeleri için güdülenmeleri ve eşliğin meslek yaşantısında ne kadar önemli bir boyut olduğunun farkına varmaları gerekmektedir. Bu farkındalık ile bir müzik öğretmeninin henüz öğrenci iken eşlik ile ilgili daha fazla pratik yapmaya başlaması beklenen bir davranıştır. Özen (1998) yapmış olduğu "Gazi Üniversitesi Gazi Eğitim Fakültesi Müzik Eğitimi Bölümü Son Sınıf Öğrencilerinin Piyanoyu Müzik Öğretmenliğinin Gerekleri Doğrultusunda Kullanma Becerileri” adlı çalışmada, öğrenciler ile piyano dersi öğretim elemanlarının piyanonun eşlik çalgısı olarak mesleki yaşantıda kullanımının önemi konusunda farklı görüşlere sahip olduklarını ortaya koymaktadır. Bilgin (1998) tarafından yapılan "İlköğretim Okullarının 2. Kademesinde Müzik Eğitiminde Kullanılan Şarkıların Gazi Üniversitesi Gazi Eğitim Fakültesi Müzik Eğitimi Bölümü Çıkışlı Müzik Öğretmenleri Tarafından Piyano ile Eşliklenmesi” adlı doktora tezinde, öğrencilerin piyano dersinde program hedefleri doğrultusunda büyük ölçüde başarılı oldukları, ancak meslek yaşantılarında okul şarkılarını öğretirken eşlik yapamadıkları ve bu konuda eksik kaldıklarını ve bu sorunu çok geç fark ettikleri sonuçlarını elde etmiştir.

Dağdeviren (2006) tarafından yapılan "Müzik Öğretmeni Yetiştiren Kurumlarda Piyanoda Eşlik Öğretimi” adlı çalışmada, eğitim müziği alanında, müzik ders kitaplarında hiç olmamakla birlikte, yardımcı ders kitapları içlerinde çoğunlukla eşlikleri olmayan şarkılar bulunduğunu, eşlikli okul şarkıları, marşlar, dağarcık kitapları gerek müzik öğretmenliği programı ana bilim dalı öğrencilerinin, gerekse müzik öğretmenlerinin dikkatini çekmediğini, ilgisizliğin temel nedenlerinin öğretmen adaylarının eşlikli şarkıları çalamayacaklarını ve bu amaca uygun eğitim almadıklarını düşünmelerinden kaynaklandığı sonuçlarını elde etmiştir. Çizili (2000) tarafından yapılan "Müzik Öğretmenliği Programları Mezunlarının Piyano Derslerinde Öğrendikleri Davranışları Öğretmenlikte Kullanmaları" konulu araştırmada, eşlik eğitimine yönelik çalışmalara ağırlık verilmesi gerektiğini ifade etmiştir. Akçalı (2007) tarafından yapılan "Müzik Öğretmenlerinin Eğitim Müziğinde Çoksesli Eşliklemeye Yaklaşımları ve Eşlikte Harf Şifre Yöntemini Kullanma Durumları" adlı yüksek lisans tezinde, müzik öğretmenlerinin derslerde eşlik yapmanın öneminin yeteri kadar farkında olmadığı, müzik öğretmenleri tarafından kullanılan kaynaklarda çoksesli eşlikle ilgili teorik bilgi ve akor bulunmadığ 1 sonuçlarına ulaşmıştır.

Yapılan araştırmada müzik öğretmenlerinin derslerde eşlik yapmanın derse katılımın artmasına yardımcı olduğu, dersi daha keyifli ve çekici hale getirdiğini düşündükleri, eşlik yapmanın, öğrencilerin şarkıları doğru ritim ile söylemelerine/çalmalarına ve şarkıları tonda kalarak daha rahat okumalarına katkı sağladığı yönünde görüş bildirdikleri tespit edilmiştir.

Bilgin \& Şaktanlı (2007) yapmış oldukları, "Okul Şarkılarının Müzik Öğretmeni Tarafından Piyano ile Eşliklenmesi” adlı çalışmada, şarkı öğretiminde eşlik yapılmasının öğrencilerde istendik davranış değişikliklerinin gerçekleşmesinde önemli bir rol oynadığını, şarkıların eşlik ile daha kolay ve çok 
amaçlı gerçekleştiğini ifade etmişlerdir. Petzold (1966) yapmış olduğu "İlk Altı Sinıftaki Çocuklar Tarafından Müzikal Seslerin İşitsel Algılanışı” adlı çalışmasında, basit akor kullanımının çocuklara daha doğru şarkı söyleme hassasiyeti sağladığı sonucuna ulaşmıştır.

Müzik öğretmenlerinin derste eşlik kullanmasının öğrenciler açısından oldukça fazla kazanımı olduğu görülmektedir. Öğrencilerin müzikal beğenisini ve müzikalitesini arttıracak olan bu davranış, öğretmenler tarafından yeterli düzeyde kullanıldığında olumlu sonuçlar elde edileceği söylenebilir. Günümüzde öğrenciler tarafından rol model alınabilecek bir kişi olan müzik öğretmenin derslerde eşlik çalarak öğrencilerin müziğe olan ilgisini arttırması ve öğrencide bir enstrüman çalma isteği oluşturması beklenen bir durumdur.

Müzik öğretmenlerinin Milli Eğitim Bakanlığı kitabında yer alan şarkıların büyük çoğunluğunu, belirli gün ve haftalarda ise, marşlar ve halk türkülerinden oluşan bir repertuvar kullandıkları tespit edilmiştir. Lisans eğitimi programında yer alan dersler içerisinde Eğitim Müziği Dağarı dersi yer almaktadır. YÖK (2006) tarafindan, Eğitim Müziği Dağarı dersinin tanımı, 'İlköğretim ve orta öğretime yönelik genel müzik eğitiminin hedeflerine uygun olarak başta ders içi olmak üzere ders diş1, okul içi ve dışındaki tüm müziksel etkinliklerin verimli ve etkili bir şekilde yürütülmesi için ilk ve orta öğretim müzik programlarında öngörülen amaçların öğrenciye kazandırılmasında ve geliştirilmesinde eğitim-öğretim malzemesi olarak kullanılmak üzere belli amaçlar, eğitim-öğretim ilkeleri ve estetik ölçütlere uygun olarak seçilen örnekler' şeklinde yapılmıştır. Buradan hareketle, lisans mezunlarının mesleki yaşantılarında bu dağarı kullandıkları düşünülmektedir. Bununla birlikte Dağdeviren'e (2006) göre, eğitim müziği alanında, müzik ders kitaplarında Piyano Eşlikli Eğitim Müziği şarkıları hiç bulunmamakla birlikte, yardımcı ders kitaplarında da çoğunlukla eşlikleri olmayan şarkılar bulunmaktadır. Yayınlanan eşlikli okul şarkıları, marşlar, dağarcık kitapları gerek müzik öğretmenliği programı ana bilim dalı öğrencilerinin, gerekse müzik öğretmenlerinin dikkatini çekmemektedir." Araştırma için öğretmenlerin görüşleri doğrultusunda belirlenen şarkıların Eğitim Müziği Dağarı dersi kapsamında öğrencilere aktarılması ve incelenmesi beklenen bir durumdur. Lisans programı derslerinin birbirileri ile olan ilişkisel durumu göz önüne alındığında, Eğitim Müziği Besteleme, Piyano, Armoni-Kontrpuan-Eşlik dersleri ve Eğitim Müziği Dağarı derslerinin birbirileri ile eşgüdümlü olarak işlenmesi, var olan dağarın teori ve uygulama boyutlarında bir bütün olarak ele alınması lisans eğitimi programının bütünlüğü açısından beklenen bir durumdur.

\section{1. Öneriler}

- Müzik öğretmenlerinin faydalanabileceği kaynak kitap sayısı artırılabilir ve öğretmenler tarafından çalınabilecek düzeyde eşlikler materyal olarak hazırlanarak öğretmenlerin kullanımına sunulabilir.

- Daha iyi bir müzik dersinin yürütülebilmesi için müzik dersine yönelik fiziki şartların iyileştirilmesi sağlanabilir.

- Lisans eğitimi süresince eşlik yapabilmenin önemi konusunda müzik öğretmeni adayları bilinçlendirilmeli ve bu doğrultuda eğitim almaları sağlanabilir.

- Lisans eğitimi süresince eşlik eğitimi ile ilgili bağlantısı olduğu düşünülen dersler arasında eşgüdüm sağlanmalı ve eşlik eğitiminin daha sağlıklı biçimde yürütülmesi şeklinde sağlanabilir.

- Lisans eğitimi süresince eşlik yapabilmek için gerekli olan armoni eğitimi büyük bir titizlikle verilmeli, örnek eşlikler armonik açıdan incelenmeli, farklı modeller ile eşlikleme konusunda eğitim verilebilir.

- Eşlik yapabilmek konusunda kendilerini yetersiz gören müzik öğretmenlerine yönelik hizmetiçi eğitimler kapsamında en yakın müzik eğitimi verilen kurumdan eğitim talebinde bulunulmalı ve müzik öğretmenlerinin eksikliklerini gidermeleri sağlanabilir. 
- Eşlik çalmanın birlikte şarkı söyleme becerisine olan katkısının önemi üzerinde durulabilir.

\section{Kaynakça}

Akçalı, O. G. (2007). Müzik öğretmenlerinin eğitim müziğinde çoksesli eşliklemeye yaklaşımları ve eşlikte harf şifre yöntemini kullanma durumları (Yüksek lisans tezi). YÖK Tez veri tabanından erişildi (Tez no: 205950).

Bilgin, S. (1998). İlköğretim okullarının ikinci kademesinde müzik eğitiminde kullanılan şarkıların Gazi Üniversitesi Gazi Eğitim Fakültesi müzik eğitimi çıkışl müzik öğretmenleri tarafindan piyano ile eşliklenmesi (Doktora tezi). YÖK Tez veri tabanından erişildi (Tez no: 76391).

Bilgin, S., \& Şaktanlı, S. C. (2007). Okul şarkılarının müzik öğretmeni tarafından piyano ile eşliklenmesi. Buca Eğitim Fakültesi Dergisi, 21, 130-133.

Bozkaya, İ. (2001). Okul ortamında müzik. Bursa: F. Özsan Matbaacılık.

Çizili, İ. (2000). Müzik öğretmenliği programları mezunlarının piyano derslerinde öğrendikleri davranışları ögretmenlikte kullanmaları (Yüksek lisans tezi). YÖK Tez veri tabanından erişildi (Tez no: 96081).

Dağdeviren, M. (2006). Müzik öğretmeni yetiştiren kurumlarda piyanoda eşlik öğretimi. A. Yayla \& F. Yayla, (Ed.). Ulusal Müzik Eğitimi Sempozyumu bildiriler kitabı (s.311-315) içinde. Denizli: Pamukkale Üniversitesi.

Demirtaş, S. (2011). Illköğretim 7. sınıf müzik dersinde şarkaların piyano eşlikli ögretilmesinin öğrenci kazanımlarına etkileri (Yüksek lisans tezi). YÖK Tez veri tabanından erişildi (Tez no: 286638).

Eğilmez, O. H. (2003). Türkiye'de müzik öğretmeni yetiştiren kurumlardaki piyano öğretiminin müzik ögretmenlerinin müzik derslerinde piyano/elektronik orgu kullanabilme yeterliklerine ilişkin görüşleri doğrultusunda değerlendirilmesi (Doktora tezi). YÖK Tez veri tabanından erişildi (Tez no: 133938).

Gülhan, N. (1990). Orta dereceli okullardaki müzik eğitiminde piyanonun bir eşlik çalgısı olarak kullanılabilirliği (Yüksek lisans tezi). YÖK Tez veri tabanından erişildi (Tez no: 19434).

Karasar, N. (2011). Bilimsel araştırma yöntemleri. Ankara: Nobel Yayın Dağıtım.

Kardeş, B. (2013). Ĕ̌itim fakültesi güzel sanatlar eğitimi bölümü müzik eğitimi anabilim dalı programlarında kazandirılan eşlik yapabilme becerisinin program hedeflerine ulaşma durumu (Yüksek lisans tezi). YÖK Tez veri tabanından erişildi (Tez no: 384159).

Koçak, B. (2001). Müzik eğitimcisi yetişstiren kurumlardaki piyano ile eşlik faaliyetleri (Yüksek Lisans Tezi). YÖK Tez veri tabanından erişildi (Tez no: 107190).

Kutluk, Ö. (2001). Türkiye'deki müzik ögretmeni yetiştiren kurumlarda piyano eğitimi (Doktora tezi). YÖK Tez veri tabanından erişildi (Tez no: 114821).

Mark, M. L. (1996). Contemporary music education. Boston: Schirmer Books.

Milli, M. S. (1999). İlköğretim okullarında piyano ve klavyeli çalgıların müzik öğretmenleri tarafindan kullanımı ve eğitime katkıları (Yüksek lisans tezi). YÖK Tez veri tabanından erişildi (Tez no: 81373).

Özen, M. (1998). Gazi Üniversitesi Gazi Eğitim Fakültesi Müzik Eğitimi Bölümü son sinıf ögrencilerinin piyanoyu müzik ögretmenliğinin gerekleri doğrultusunda kullanma becerileri (Doktora tezi). YÖK Tez veri tabanından erişildi (Tez no: 76414). 
Öztürk, G. (2001). Illköğretim kurumlarında görev yapmakta olan müzik öğretmenlerinin çalgılarını kullanmadaki yeterlilik durumları (Yüksek lisans tezi). YÖK Tez veri tabanından erişildi (Tez no: 107163).

Parasız, G. (2018). Ortaokul öğrencilerinin müzik beğenileri ve müzik dersinden beklentileri. G. Mıhladız (Ed.), Eğitim Bilimlerinde Akademik Araştırmalar (s. 253-273) içinde. Ankara: Gece Kitaplı̆̆ı.

Petzold, R. G. (1966). Auditory perception of musical sounds by children in the first six grades (Cooperative Research Project No. 1051). Madison, WI: University of Wisconsin.

Propst, T. G. (2003). The relationship between the undergraduate music methods class curriculum and the use of music in the classrooms of in-service elementary teachers. Journal of Research in Music Education, 51 (4), 316-329.

Sezgin, F. (2015). Ölçme ve değerlendirmede temel istatistiksel işlemler. E. Karip (Ed.), Ölçme ve değerlendirme (s. 51-88) içinde. Ankara: Pegem Akademi.

Sönmez, V., Alacapınar, F. G. (2011). Örneklendirilmiş bilimsel araştırma yöntemleri. Ankara: Anı Yayıncilik.

Uçan, A. (1996). İnsan ve müzik, insan ve sanat eğitimi, temel kavramlar-ilkeler-yaklaşımlar, Türkiye'de cumhuriyetin ilk yetmiş yılındaki durum. Ankara: Müzik Ansiklopedisi Yayınları.

Yüksek Öğretim Kurulu. (2006). Ĕgitim fakülteleri ögretmen yetiştirme programlarının yeniden düzenlenmesi. Ankara: YÖK Yayını. Erişim adresi: http: //www.yok.gov.tr/ documents/10279/49665/muzik_ogretmenligi.pdf/831bd1ff-e3cb-4d2e-bbf8-cf80f6d0e209/ 